\title{
The Replacement of Resistance Welding with Laser Beam Welding
}

\author{
Anna MALOVECZKY, ${ }^{1}$ Ambrus KARAI ${ }^{2}$ \\ Bay Zoltán Non-profit Ltd. for Applied Research, Budapest, Hungary \\ ${ }^{1}$ anna.maloveczky@bayzoltan.hu \\ 22ambrus.karai@bayzoltan.hu
}

\begin{abstract}
Resistance welding has long been successfully used in the automotive industry, but nowadays, there are even more advanced technologies, such as laser beam welding, which is a much faster, more economical and flexible technology. During our work, we have mapped the possibility of replacing resistance welding with laser beam welding. Furthermore, we have found a solution to the problems occurring during laser beam welding. The biggest challenge in laser beam technology is that the zinc coating on the steel plates (required to prevent corrosion) evaporates during welding, resulting in pores, and leading to a significant reduction in weld strength. We have solved that by using spacer sheets, which allow the zinc vapour to escape from the keyhole.
\end{abstract}

Keywords: laser welding, resistance welding, spot welding.

\section{Introduction}

Laser beam welding is gaining ground in a wide range of industries [1, 2]. The reason for its spread is in its favourable technological parameters:

- precision, accurate control of the technological parameters;

- high machining speed;

- excellent machining quality (post-processing needs are reduced or cancelled)

- no force affects the work piece;

- wide range of selectable, and precisely con-trollable energy densities in machining;

- small specific thermal stress on the work piece;

- the machining tool is abrasion-free and unaffected by the direction of machining (light);

- excellent automation;

- economical production;

- great manufacturing flexibility;

- good compatibility with other technologies [3].

However, there are a number of challenges in laser beam welding:

Steel sheets are usually coated with a zinc layer for corrosion resistance. Due to the low boiling point of zinc, it vaporizes intensively during welding. Thus, it makes the keyhole unstable and it is able to create such vapour pressure over the weld seam that the molten metal splashes out of the plasma channel (sputtering weld). In addition, zinc vapour bubbles can also be incorporated into the weld. As a result, the weld strength significantly decreases.

During the research, several methods have been tried in order to eliminate the zinc vapour problem [4-23]. However, they have been either ineffective or have made the production too cumbersome. According to our idea, with a plastic forming, small bumps can be created on the surface of the plate, which serves as spacers during the welding process. The experiments were carried out with a spacer sheet solution since the two solutions are the same, but the bumpy version is also in place during manufacturing and industrial applications.

\section{Materials and methods}

The welding experiments were performed using a Trumpf TruLaser Cell 7020 5D Laser Machining Centre with Trumpf TruDisk 4001 laser radiation source. First, blind welds were made and then steel sheet pairs were welded. Sheet pairs were made using spacer sheets, and also sheet pairs with no gap in between them. The most important 
welding parameters were the following; laser power 1,000 W, welding speed $3 \mathrm{~m} / \mathrm{min}$ [24]. The focal point of the laser beam was set to 1 and 4 $\mathrm{mm}$ (defocus) relative to the surface of the upper sheet. The plates to be welded were cold rolled, with a thickness of $0.6 \mathrm{~mm}$ and with galvanized zinc coating. The thickness of the spacer sheets was $0.1 \mathrm{~mm}$. During welding, the plates were clamped together with the spacer sheets placed between them. For the metallographic examination, the plates were cut with a water-cooled disc cutter, then ground polished and finally etched with $3 \%$ nital solution.

A VHX J20 Keyence digital light microscope was used to examine the welds and to take im-ages.

\section{Results and discussion}

Figures 1-3., show light microscopic images of the welds produced with a $4 \mathrm{~mm}$ defocus, and Figures 4-6. show images with $1 \mathrm{~mm}$ defocus. The most important dimensions of the seams are shown in Table 1.

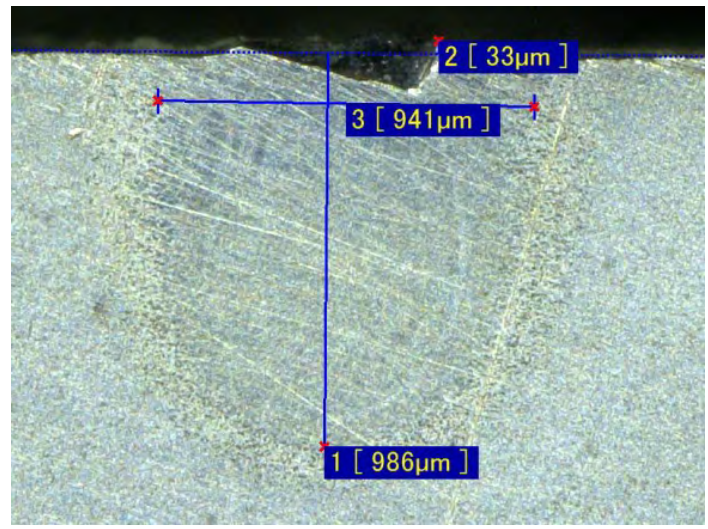

Figure 1. Picture of blind weld with $4 \mathrm{~mm}$ defocus

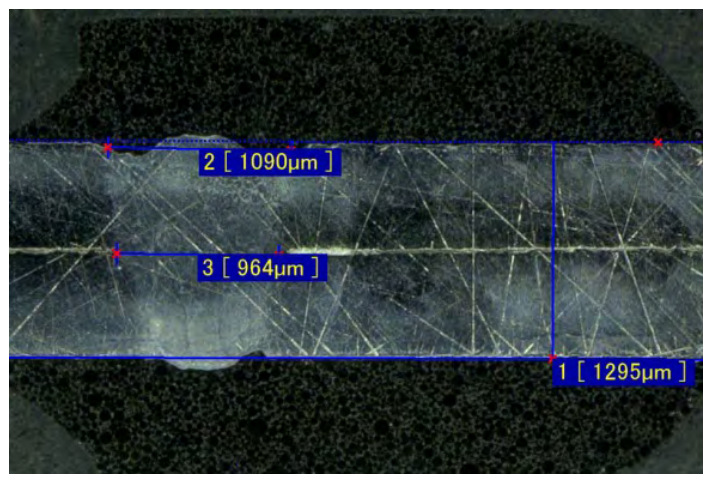

Figure 2. Picture of weld without gap, with $4 \mathrm{~mm}$ defocus

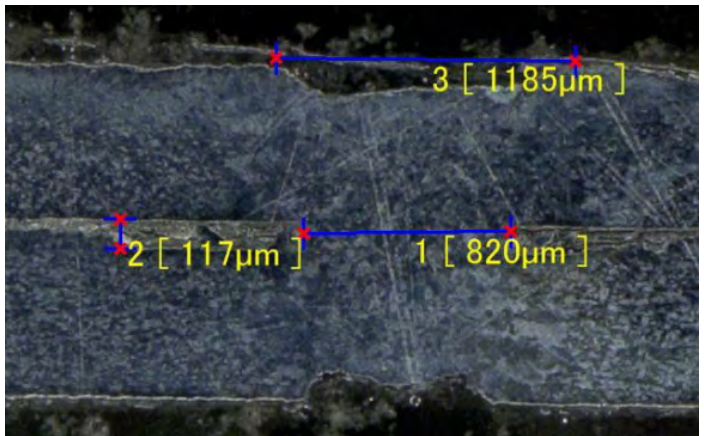

Figure 3. Picture of weld with spacer sheets, with 4 mm defocus

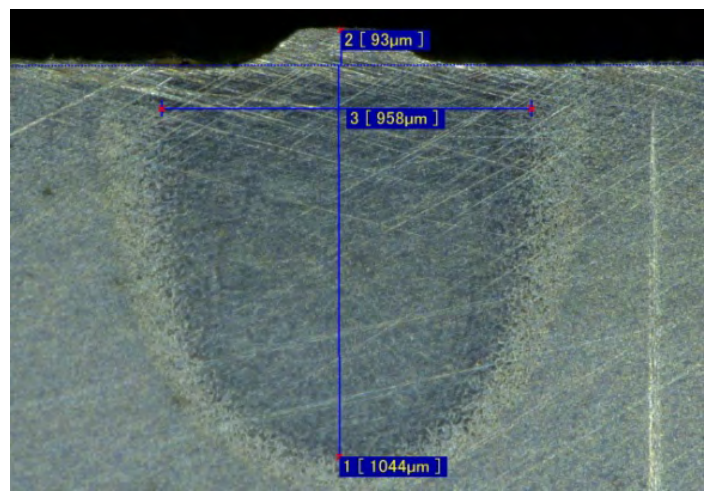

Figure 4. Picture of blind weld with $1 \mathrm{~mm}$ defocus

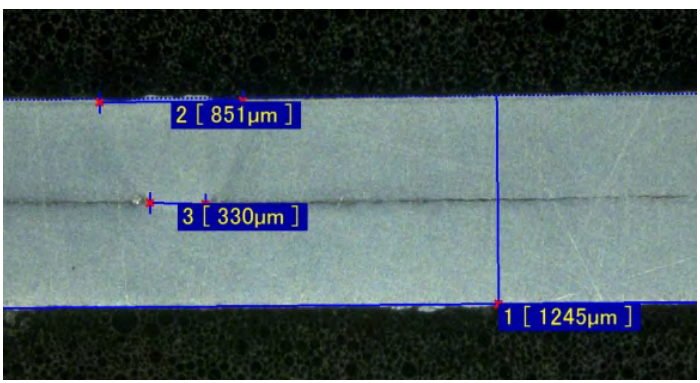

Figure 5. Picture of weld without gap, with $1 \mathrm{~mm}$ defocus

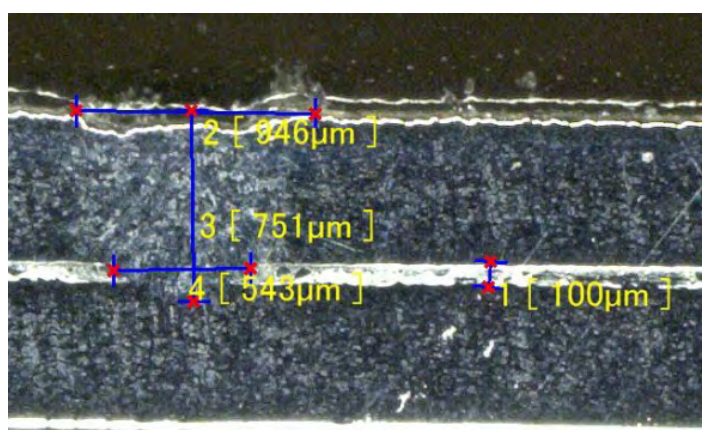

Figure 6. Picture of weld with spacer sheets, with $1 \mathrm{~mm}$ defocus 
Table 1. Dimensions of the welds

\begin{tabular}{|c|c|c|c|}
\hline $\begin{array}{c}\text { Defo- } \\
\text { cus } \\
(\mathbf{m m})\end{array}$ & Type & $\begin{array}{c}\text { Weld depth } \\
(\boldsymbol{\mu m})\end{array}$ & $\begin{array}{c}\text { Face } \\
\text { width } \\
(\boldsymbol{\mu} \mathbf{m})\end{array}$ \\
\hline 4 & blind weld & 986 & 941 \\
\hline 4 & without gap & -(melted through) & 1090 \\
\hline 4 & with spacer sheets & -(melted through) & 1185 \\
\hline 1 & blind weld & 1044 & 958 \\
\hline 1 & without gap & 732 & 851 \\
\hline 1 & with spacer sheets & 751 & 946 \\
\hline
\end{tabular}

On metallographic images, it is apparent that the $1 \mathrm{~mm}$ defocus value yields better results for this type of steel. Indeed, in the other cases (the non-gapped and gapped samples) the bottom plate was melted through because the laser power was too high.

Furthermore, $0.1 \mathrm{~mm}$ gaps can be observed in the spacer sheet solution. Splashes and pores are not visible even when the gap is not set because the plates are very thin.

\section{Conclusions}

The biggest disadvantage of resistance spot welding is that it is not able to adapt quickly to inflexible technology, i.e. fast changes in the automotive industry. Resistance welding is a slow process, and it is costly because heating up the work piece by electrodes requires a large amount of energy input.

Laser welding (especially in the case of re-mote welding) has a high machining speed, is highly automated, combines well with other technologies, and has high manufacturing flexibility. Furthermore, it is very precise, and there is no need for rework. The cost of in-vestment in laser remote welding is higher, but production is much more economical as well as welding parameters can be kept precisely in hand so good weld quality is guaranteed.

Steels are usually coated with a zinc coating for corrosion resistance, but this zinc coating causes serious problems during welding.

During welding, zinc vapour is formed, which incorporates into the weld and makes it porous.

In any case, the high vapour pressure makes the keyhole unstable and it is able to create such vapour pressure over the weld that the molten metal splashes out of the keyhole (sputtering weld). As a result, the weld strength is greatly reduced.
This problem has been solved by installing spacer sheets between the plates so that the zinc vapour could escape. During these test weldings, no splashes or pores were found.

In addition, the appropriate laser parameters have been experimented with for the plate thickness and type of material to be used

\section{Acknowledgements}

We would like to thank the Edutus College and its employees who have made it possible for us to carry out our experiments at the premises and to the staff of Bay Zoltán Applied Research Ltd. who supported our work with their advice and help.

\section{References}

[1] Bagyinszki Gy., Bitay E.: Hegesztéstechnika I. Eljárások és gépesítés. EME, Cluj-Napoca, 2010. https://eda.eme.ro/handle/10598/15437

[2] Bitay E.: Lézeres felületkezelés és modellezés. EME, Cluj-Napoca, 2007.

https://eda.eme.ro/handle/10598/8923

[3] Búza G.: Lézersugaras technológiák I. Edutus Főiskola, Budapest, 2012. 10.

[4] Kyung-Min H., Yung C. S.: Prospects of laser welding technology in the automotive industry: A review. Journal of Materials Processing Technology, 245. (2017) 52-54.

https://doi.org/10.1016/j.jmatprotec.2017.02.008

[5] Akhter R., Steen W. M., Cruciani D.: Laser welding of zinc coated steel. Proceedings of 6th International Conference Lasers in Manufacturing (1989), 105-120.

[6] Chen G., Mei L., Zhang M., Zhang Y., Wang Z.: Research on key influence factors of laser overlap welding of automobile body galvanized steel. Optics \& Laser Technology, 45/1. (2013) 726-733. https://doi.org/10.1016/j.optlastec.2012.05.002

[7] Chen H. C., Pinkerton A. J., Li, L. Liu Z., Mistry A. T.: Gap-free fibre laser welding of Zn-coated steel on Al alloy for light-weight automotive applications. Materials \& Design, 32/2. (2011) 495-504. https://doi.org/10.1016/j.matdes.2010.08.034

[8] Chen W., Ackerson P. , Molian P.: $\mathrm{CO}_{2}$ laser welding of galvanized steel sheets using vent holes. Materials \& Design, 30/2. (2009) 245-251. https://doi.org/10.1016/j.matdes.2008.05.009

[9] Graham M. P., Kerr H. W., Weckman D. C.: Laser welding of $\mathrm{Zn}$-coated sheet steels, Proceedings of SPIE, 2703. (1996) 170-180.

[10] Graham M. P., Hirak D. M., Kerr H. W., Weckman D. C.: Nd:YAG laser welding of coated sheet steel. Journal of Laser Applications, 6/4. (1994) 212-222.

https://doi.org/10.2351/1.4745359 
[11] Gu H.: Laser lap welding of zinc coated steel sheet with laser-dimple technology. Journal of Laser Applications, 22/3. (2010) 87-89. https://doi.org/10.2351/1.3485596

[12] Lee S. J., Katayama S., Kawahito Y., Kinoshita K., Kim J. D.: Weldability and keyhole behavior of $Z n$-coated steel in remote welding using disk laser with scanner head. Journal of Laser Applications, 25/3. (2013) 032008. https://doi.org/10.2351/1.4795456

[13] Mei L., Chen G., Yan D., Xie D., Ge X., Zhang M.: Impact of inter-sheet gaps on laser overlap welding performance for galvanised steel. Journal of Materials Processing Technology, 226. (2015) 157-168.

https://doi.org/10.1016/j.jmatprotec.2015.07.020

[14] Bley H., Weyand L., Luft A.: An alternative approach for the cost-efficient laser welding of zinc-coated sheet metal. CIRP Annals, 56/1. (2007) 17-20. https://doi.org/10.1016/j.cirp.2007.05.006

[15] Pieters R. R. G. M., Bakels J. G., Hermans M. J. M., Den Ouden G.: Laser welding of zinc coated steels in an edge lap configuration. Journal of Laser Applications, 18/3. (2006) 199-204. https://doi.org/10.2351/1.2227022

[16] Iqbal S., Gualini M. M., Rehman A.: Dual beam method for laser welding of galvanized steel: experimentation and prospects. Optics \& Laser Technology, 42/1. (2010) 93-98.

https://doi.org/10.1016/j.optlastec.2009.05.009

[17] Li X., Lawson S., Zhou Y., Goodwin F.: Novel technique for laser lap welding of zinc coated sheet steels. Journal of Laser Applications, 19/4. (2007) 259-264.

https://doi.org/10.2351/1.2795755
[18] Yih-fong T.: Gap-free lap welding of zinc-coated steel using pulsed $\mathrm{CO}_{2}$ laser. International Journal of Advanced Manufacturing Technology, 29/3-4. (2006) 287-295.

https://doi.org/10.1007/s00170-005-2522-3

[19] Tzeng Y. F., Chen F. C.: Effects of operating parameters on the static properties of pulsed laser welded zinc-coated steel. International Journal of Advanced Manufacturing Technology, 18/9. (2001) 641-647. https://doi.org/10.1007/s001700170024

[20] Ma J., Harooni M., Carlson B., Kovacevic R.: Dissimilar joining of galvanized high-strength steel to aluminum alloy in a zero-gap lap joint configuration by two-pass laser welding. Materials \& Design, 58. (2014) 390-401. https://doi.org/10.1016/j.matdes.2014.01.046

[21] Ma J., Kong F., Carlson B., Kovacevic R.: Twopass laser welding of galvanized high-strength dual-phase steel for a zero-gap lap joint configuration. Journal of Materials Processing Technology, 213/3. (2013) 495-507.

https://doi.org/10.1016/j.jmatprotec.2012.10.019

[22] Yang S., Kovacevic R.: Laser welding of galvanized DP980 steel assisted by the GTAW preheating in a gap-free lap joint configuration. Journal of Laser Applications, 21/3. (2009) 139-148. https://doi.org/10.2351/1.3184432

[23] Milberg J., Trautmann A.: Defect-free joining of zinc-coated steels by bifocal hybrid laser welding. Production Engineering, 3/1. (2009) 9-15. https://doi.org/10.1007/s11740-008-0140-2

[24] Kovács T.: Laser Welding Process Specification Base on Welding Theories. Procedia Manufacturing, 22. (2018) 147-153.

https://doi.org/10.1016/j.promfg.2018.03.023 